\title{
Some factors related to protoplast culture and plant regeneration from leaf mesophyll protoplasts of Magdeburg chicory (Cichorium intybus L var Magdeburg)
}

\author{
C Rambaud, J Dubois, J Vasseur \\ Université des Sciences et Techniques de Lille-Flandres Artois, \\ Laboratoire de Physiologie de la différenciation et biotechnologies végétales, \\ 59655 Villeneuve d'Ascq, France
}

(Received 9 April 1990; accepted 24 September 1990)

\begin{abstract}
Summary - Conditions have been established for efficient plant regeneration from protoplasts of the cultivar Pevele of Cichorium intybus $L$ var Magdeburg. In order to increase the yield of protoplasts which are able to undergo cell divisions during the first week of culture, protoplasts of Magdeburg chicory were cultured in a Murashige and Skoog (1962) modified medium containing $2 \mathrm{mg} / \mathrm{ANA}, 1 \mathrm{mg} / \mathrm{BA}, 10 \mathrm{~g} / \mathrm{l}$ sucrose, a mixture of glutamine- $\mathrm{KNO}_{3}$ as nitrogen source and were placed at a temperature of $30^{\circ} \mathrm{C}$. With this method, cell walls can be regenerated within $24 \mathrm{~h}$ and after a lapse of 1-2 d, cell division became apparent and continuous divisions led to callus formation and then to plantlet regeneration. Special emphasis has been paid to leaf material for protoplast culture. Donor plantlets, aged 14 d and cultivated in a photoperiod of $16: 8 \mathrm{~h}$ under a light intensity of $15 \mathrm{~W} \cdot \mathrm{m}^{-2}$ (fluorescent light tubes "Deluxe Cool White") gave a better yield of microcalli. These were then incorporated in a proliferation medium containing agarose at low gel temperature. During this phase it is better to use Petri dishes of large diameter regardless of the amount of microcalli transferred.
\end{abstract}

protoplast / regeneration / Cichorium intybus $L$ var Magdeburg

Résumé - Quelques facteurs liés à la culture et la régénération de protoplastes issus du mésophylle de feuilles de chicorée de Magdebourg (Cichorium intybus $L$ var Madgebourg). Nous avons déterminé les conditions nécessaires à la régénération de plantes à partir de protoplastes du cultivar Pévèle de Cichorium intybus $L$ var Magdebourg. De manière à augmenter le nombre des cellules capables de se diviser durant la $1^{r e}$ semaine, les protoplastes de chicorée de Magdebourg sont cultivés à $30^{\circ} \mathrm{C}$, sur un milieu de Murashige et Skoog (1962) modifié, contenant $2 \mathrm{mg} / \mathrm{INA}, 1 \mathrm{mg} / \mathrm{BA}, 10 \mathrm{~g} / \mathrm{l}$ saccharose et un mélange de glutamine-KNO $\mathrm{K}_{3}$ comme source azotée. De cette manière les parois cellulaires se reforment en $24 h$ et après $1-2 j$, les divisions conduisent à la formation de cals puis à la régénération de plantes. L'amélioration du rendement en microcals viables exige de prendre en compte les conditions de culture ainsi que l'âge des plantules sur lesquelles seront prélevées les feuilles à l'origine des protoplastes. C'est avec des plantules donatrices, âgées de $14 j$, et cultivées en photopériode $16: 8$ sous une intensité lumineuse de 15 W.m. $\mathrm{m}^{2}$ fournie par des tubes fluorescents de type "Deluxe Cool White», que le rendement en microcals est le meilleur. Les microcals sont ensuite incorporés dans un milieu de prolifération contenant l'agarose à basse température de gélification. Durant cette phase, il est préférable d'utiliser des boîtes de Petri de grand diamètre, quelle que soit la quantité de microcals transférés.

protoplaste / régénération / Cichorium intybus $L$ var Madgebourg

\section{INTRODUCTION}

The ability to isolate, to culture plant protoplasts with high efficiency and to regenerate plants derived from single protoplast is one of the prerequisites for crop improvement through mutation, somatic hybridization or genetic modification by introduction of foreign DNA. However, successful regeneration of plants from isolated proto- plasts is dependent on many factors and a systematic analysis of these is extremely difficult.

A very important event in plant regeneration is the transition from microcalli obtained in the first step (issued from cellular divisions in liquid medium) to the stage of minicalli where the growth takes place in a solid medium. With reference to vegetable species, it is necessary to consider examples pertaining to agar type (Shillito et al, 
1983; Tremblay et al, 1985; Szabados and Roca, 1986), plating methods (Ludwig et al, 1985) and cellular density (Shneyour et al, 1984).

Mesophyll protoplasts isolated from the leaves of Cichorium intybus $L$ var Witloof cv Zoom are able to regenerate whole plants (Saksi et al, 1986). In this species, which harbours many cultivars, genetic factors interfere with the ability to regenerate plants (Crepy et al, 1982). The study of the various factors implicated in the regeneration of plants is necessary and must be repeated for each cultivar.

With a view to developing new techniques of somatic hybridization or somatic cybrid obtainment from Cichorium intybus $L$ var Magdeburg cv Pévèle, regeneration of plants from protoplasts of this cultivar has been performed. In this paper, we describe some of the conditions necessary to obtain an efficient and reproducible culture with a high yield of microcalli. These conditions are:

- the preconditioning of the donor plants;

- the protoplast culture and the transfer of microcalli of gelified medium to prevent necrosis and to allow plant regeneration.

\section{MATERIAL AND METHODS}

Akenes of Cichorium intybus $\mathrm{L}$ var Magdeburg cv Pévèle were surface sterilized by a solution of $0.1 \%$ $\mathrm{HgCl}_{2}$, washed 3 times in sterile distilled water and placed in Petri dishes on a Heller (1953) culture medium (major and minor salts without $\mathrm{FeCl}_{3}$ ) supplemented with $19.5 \mathrm{mg} / \mathrm{Fe}-E D T A, 20 \mathrm{~g} / \mathrm{l}$ sucrose and $6 \mathrm{~g} / \mathrm{l}$ Agar (Biokar Type E). Aseptic seeds were then transferred to culture tubes in the same medium.

After 12-14 d of culture, leaves were removed from young plants, torn and incubated in the washing medium containing $10 \mathrm{~g} / \mathrm{l}$ Caylase $345^{*}, 0.5 \mathrm{~g} / \mathrm{l}$ Caylase $\mathrm{M}_{2}$ (Dubois et al, 1990) and $90 \mathrm{~g} / \mathrm{l}$ mannitol (" Cayla Co, Toulouse, France).

After $5 \mathrm{~h}$ of incubation at $30^{\circ} \mathrm{C}$ in darkness, without agitation, protoplasts were purified by infiltration through a 50- $\mu \mathrm{m}$ steel mesh, collected and washed three times by low speed centrifugation (100 g) for 10 $\min$.

The washing medium consisted of the culture medium without growth substances and the nutrient medium $\left(M_{1}\right)$ was used for the culture of protoplasts of Witloof chicory (Saksi et al, 1986) after the study of the nature and the concentration of the prevailing substances.

Cultures were initiated at a density of 20000 protoplasts per $\mathrm{ml}$ in $55 \mathrm{~mm}$ Petri dishes (5 $\mathrm{ml}$ per dish), sealed with parafilm and incubated in darkness in a growth chamber at $30^{\circ} \mathrm{C}$ for $7 \mathrm{~d}$ (Wali Alami-Fathi, 1987). At the end of this stage, microcalli derived from protoplasts were transferred to an agarose medium $\left(\mathrm{MC}_{2}\right)$ so as to obtain their proliferation (Saksi et al, 1986). When the minicalli reached the size of $2-3 \mathrm{~mm}$, they were induced to form buds in a gelified medium (Agar $5 \mathrm{~g} / \mathrm{l}$ ) containing MS (Murashige and Skoog, 1962) major salts, Fe-EDTA at half strength, Heller (1953) minor salts, sucrose (5 g/l, BA (0.1 mg/l) and Morel and Wetmore (1951) vitamins. Roots were induced by transferring buds on Heller (1953) medium supplemented with $10 \mathrm{~g} / \mathrm{sucrose}$. The plants were then transferred to a greenhouse.

The plating efficiency was defined by counting the number of divided cells (7th d) on a Nageotte numeration cell or as the percentage of proliferated minicalli (45th d) corresponding to the number of plated protoplasts.

\section{RESULTS}

Magdeburg chicory protoplasts were isolated using Caylase enzymes during a maceration period of about $5 \mathrm{~h}$. Ten million protoplasts were obtained from $1 \mathrm{~g}$ of fresh leaves. They contained many chloroplasts and the majority of them were $30-40 \mu \mathrm{m}$ in diameter.

Few divisions took place at $24^{\circ} \mathrm{C}$. We observed more divisions at $30^{\circ} \mathrm{C}$ and when the temperature reached $35^{\circ} \mathrm{C}$ (table I), there was an almost complete inhibition of protoplast division.

\section{Donor plant culture conditions}

Plantlets of Magdeburg chicory were cultivated in growth chambers $\left(24 \pm 1^{\circ} \mathrm{C}\right.$ day/20 $\pm 1^{\circ} \mathrm{C}$ night), with different light periods (table II) and we observed that $16 \mathrm{~h}$ of daylight were necessary to obtain a high rate of mesophyll protoplast divi-

Table I. Effect of temperature culture of the first stage on plating efficiency on the 7th d (D7) (standard deviation (SD) of 4 replicate plates). Protoplasts were cultured in $M C_{1}$ medium in darkness.
$T^{\circ}$ culture
$\left({ }^{\circ} \mathrm{C}\right)$
Plating efficiency at $D 7(\%)$

$$
\begin{array}{r}
1.70 \pm 0.45 \\
14.00 \pm 1.42 \\
18.10 \pm 1.40 \\
110.80 \pm 1.98 \\
2.10 \pm 0.11
\end{array}
$$


Table II. Effect of intensity and regime of light received by the donor plants ( $14 \mathrm{~d}$-old) on plating efficiency on the 7th (D7) and 45th $d$ (D45) (SD of 4 replicate plates). Protoplasts were cultured in $\mathrm{MC}_{1}$ medium in darkness at $30^{\circ} \mathrm{C}$ and then, after $7 \mathrm{~d}$, were transferred to $\mathrm{MC}_{2}$ medium in light $(16: 8)$ at $22^{\circ} \mathrm{C}$.

\begin{tabular}{cccc}
\hline $\begin{array}{c}\text { Light } \\
\text { regime }\end{array}$ & $\begin{array}{c}\text { Light } \\
\text { intensity } \\
\left(W . m^{-2}\right)\end{array}$ & \multicolumn{2}{c}{ Plating efficiency } \\
& $(\%)$ & $D 45$ \\
\hline & & 0 & 0 \\
$0: 24$ & - & $14.0 \pm 4.75$ & 0.35 \\
$12: 12$ & 15 & 0 & 0 \\
& 3 & $19.2 \pm 2.15$ & 0 \\
$16: 08$ & 6 & $22.4 \pm 0.90$ & 0 \\
& 9 & $36.0 \pm 1.00$ & 1.85 \\
$24: 0$ & 15 & $6.4 \pm 2.40$ & 0.49 \\
\hline
\end{tabular}

sion after $7 \mathrm{~d}$ in the first phase. The light intensity received by the plantlets cultured under $16 \mathrm{~h}$ of daylight was then studied (table II). For this purpose, culture tubes were placed at various distances from the fluorescent light tubes ("Deluxe Cool White"). It was observed that plantlets receiving $15 \mathrm{~W} \cdot \mathrm{m}^{-2}$ underwent the highest number of cellular division, in the first stage.

The age of donor plants, clearly defined by the number of days after sowing, was also crucial. The best physiological stage where it is beneficial to obtain consistently high yields of viable protoplasts with the highest percentage of division (table III) is when the Magdeburg chicory plants have one or two leaves (14 d-old).

\section{Culture medium for the first step}

Crepy et al (1982) observed the complexity of nitrogen alimentation of isolated cells and proto-

Table III. Plating efficiency on the 7th (D7) and 45th (D45) $\mathrm{d}$ of protoplasts isolated from plants of different ages (SD of 4 replicate plates) and cultured at $5 \mathrm{~cm}$ of the light source (De Luxe Cool White) and at $22^{\circ} \mathrm{C}$.

\begin{tabular}{ccc}
\hline $\begin{array}{c}\text { Age of donor } \\
\text { plants (d) }\end{array}$ & D7 & $\begin{array}{c}\text { Plating efficiency } \\
\text { (\%) }\end{array}$ \\
& & $D 45$ \\
\hline & & \\
14 & $42 \pm 5.80$ & 2.49 \\
18 & $25 \pm 0.80$ & 2.07 \\
21 & $2 \pm 0.80$ & 0.50 \\
24 & $2 \pm 1.53$ & 0 \\
\hline
\end{tabular}

plasts of Cichorium species. We showed that in Magdeburg chicory (table IV), glutamine (72 mg/ I) in association with $\mathrm{KNO}_{3}(72 \mathrm{mg} / \mathrm{l})$ gave the best results, but nitrate had to be removed from the culture medium after the first week as it turned into an inhibitor. In addition, we showed that $10 \mathrm{~g} / \mathrm{l}$ sucrose was necessary to obtain optimal plating efficiency (table $\mathrm{V}$ ).

Inositol, which was part of the medium composition was also studied. By increasing the inositol concentration, higher rates of division were not observed in the first phase, but in the second one, the number of calli became more important with $250 \mathrm{mg} / \mathrm{l}$ instead of $100 \mathrm{mg} / \mathrm{l}$ in $M C_{1}$ and the calli seemed to be denser.

\section{Callus proliferation and plant regeneration}

After a period of $7 \mathrm{~d}$, microcalli were transferred to a second medium $\left(\mathrm{MC}_{2}\right)$ to prevent browning and necrosis. The old medium was removed by centrifugation and replaced by fresh medium of the same composition. The cellular suspension was then incorporated in agarose medium. This transfer was a critical step as the number of microcalli which survived at that stage was very low.

Microcalli proliferated better in agarose than in "bacto agar" (Difco) or in "agar noble" (Difco). Agarose low gel temperature (Bio-Rad) with a static gelation temperature of $37^{\circ} \mathrm{C}$ was used for this transfer and microcalli were incorporated into gelose after cooling. For some species it was better to plate microcalli on the surface of the agarose (Glimelius, 1984) but for chicory species, it was better to incorporate them directly into the agarose.

During the first stage chicory protoplasts were cultured in Petri dishes of $55 \mathrm{~mm}$ in diameter, but in the second stage, larger dishes were preferable as a greater quantity of minicalli were obtained (table Vl). We also observed that a better proliferation was obtained by transferring $1 \mathrm{ml}$ (about 8000 microcalli) per dish of $90 \mathrm{~mm}$ in diameter.

Calli proliferation also necessitated a medium with reduced osmoticum (60 g/l instead $90 \mathrm{~g} / \mathrm{l}$ mannitol), low auxin and benzyl adenine concentrations $(0.5 \mathrm{mg} / \mathrm{l})$ and as the $\mathrm{KNO}_{3}$ acted as an inhibitor in the second phase, it was completely removed (table IV).

For bud induction, mannitol and auxin were omitted and the sucrose level was lowered to 5 $\mathrm{g} / \mathrm{l}$. No further buds were obtained with $5 \mathrm{~g} / \mathrm{l}$ instead of the $10 \mathrm{~g} / \mathrm{l}$ sucrose concentration but at a later stage rooting was observed to be better. 
Table IV. Effect of nitrogen source in nutrient media of the first stage $\left(\mathrm{MC}_{1}\right)$ and the second stage $\left(M C_{2}\right)$ on plating efficiency on the 7th and 45th $d$ (SD of 4 and 3 replicate plates for D7 and D45). Protoplasts were cultured in MC $_{1}$ medium in darkness at $30^{\circ} \mathrm{C}$ and then, after $7 \mathrm{~d}$, were transferred to $\mathrm{MC}_{2}$ medium in light $(16: 8)$ at $22^{\circ} \mathrm{C}$. Gln: glutamine.

\begin{tabular}{cccc}
\hline $\begin{array}{c}\text { Nitrogen source } \\
\text { in } M C_{1} \\
(N=144 \mathrm{mg} / \mathrm{l})\end{array}$ & $\begin{array}{c}\text { Plating } \\
\text { efficiency (\%) } \\
\mathrm{D7}\end{array}$ & $\begin{array}{c}\text { Nitrogen source } \\
\text { in } M C_{2} \\
(\mathrm{~N}=144 \mathrm{mg} / \mathrm{l})\end{array}$ & $\begin{array}{c}\text { Plating } \\
\text { efficiency (\%) } \\
\text { D45 }\end{array}$ \\
\hline $\mathrm{Gln}$ & $24.00 \pm 1.50$ & $\mathrm{Gln}$ & 0.98 \\
$\mathrm{Gln}+\mathrm{KNO}_{3}$ & $38.00 \pm 1.26$ & $\begin{array}{c}\mathrm{Gln} \\
\mathrm{Gln}+\mathrm{KNO}_{3}\end{array}$ & $\begin{array}{c}1.48 \pm 0.21 \\
0.40 \pm 0.20\end{array}$ \\
\hline
\end{tabular}

Table V. Effect of sucrose concentration in $M C_{1}$ medium on plating efficiency on the 7 th and 45 th $d$ (SD of 4 and 3 replicate plates for D7 and D45). Protoplasts were cultured in $\mathrm{MC}_{1}$ medium in darkness at $30^{\circ} \mathrm{C}$ with various concentrations of sucrose and then, after $7 \mathrm{~d}$, were transferred to $M C_{2}$ medium in light (16:8) at $22^{\circ} \mathrm{C}$ with $5 \mathrm{~g} / \mathrm{l}$ sucrose.

\begin{tabular}{ccc}
\hline $\begin{array}{c}\text { Sucrose } \\
\text { concentration } \\
(g / l)\end{array}$ & $D 7$ & \multicolumn{2}{c}{ Plating efficiency } \\
& & $D 45$ \\
\hline & & \\
2.5 & $17.6 \pm 1.92$ & $0.81 \pm 0.075$ \\
5.0 & $24.8 \pm 2.16$ & $1.08 \pm 0.025$ \\
10.0 & $36.0 \pm 0.92$ & $3.05 \pm 0.570$ \\
15.0 & $28.4 \pm 2.08$ & $2.23 \pm 0.190$ \\
20.0 & $24.4 \pm 3.00$ & $1.09 \pm 0.150$ \\
\hline
\end{tabular}

Benzyl adenine was also lowered to $0.1 \mathrm{mg} / \mathrm{l}$ and the nitrogen source was changed. In the $\mathrm{MC}_{2}$ proliferation medium we used glutamine as the sole nitrogen source, but if the same nitrogen source in the induction medium was utilised, no bud appeared. With the use of half strength min- eral salt and with $\mathrm{KNO}_{3}$ and $\mathrm{NH}_{4} \mathrm{NO}_{3}$ as the nitrogen source, numerous buds were obtained. About $80 \%$ of calli gave buds, on an average of 2 per callus.

The age of the plants was also an important criterion for their regeneration; the younger the donor plants were, the more numerous the buds.

When the buds reached 4-5 mm, they were transferred, for rooting, to a Heller (1953) medium, in which $\mathrm{FeCl}_{3}$ was replaced by $19.5 \mathrm{mg} / \mathrm{l}$ Fe-EDTA, and supplemented with $10 \mathrm{~g} / \mathrm{l}$ sucrose and $6 \mathrm{~g} / \mathrm{l}$ agar. It was then possible to transfer the plantlets to a mini-greenhouse.

\section{DISCUSSION}

Several authors have reported that many plant species used for protoplast culture require a long photoperiod (16 or $18 \mathrm{~h}$ daylight); the examples quoted are: tomato (Niedz et al, 1985)) and pea (Von Arnold and Eriksson, 1976). We observed in Magdeburg chicory protoplast culture that the plating efficiency was higher than in other light conditions where donor plants were cultured un-

Table VI. Effect of plate dimension and inoculum quantity on plating efficiency 45th d (SD of 3 replicate plates). Protoplasts were first cultured in $\mathrm{MC}_{1}$ medium for $7 \mathrm{~d}$ and then transferred in various volumes (about 8000 microcalli per $\mathrm{ml}$ ) on $\mathrm{MC}_{2}$ medium, in light $(16: 8)$ at $22^{\circ} \mathrm{C}$.

\begin{tabular}{|c|c|c|c|}
\hline \multicolumn{2}{|c|}{ Small dishes ( $\varnothing 55 \mathrm{~mm}$ ) } & \multicolumn{2}{|c|}{ Large dishes (ø $90 \mathrm{~mm}$ ) } \\
\hline $\begin{array}{l}\text { Plating suspension } \\
\text { volume at } D 7(\mathrm{ml})\end{array}$ & $\begin{array}{c}\text { Plating efficiency } \\
\text { at D45 (\%) }\end{array}$ & $\begin{array}{l}\text { Plating suspension } \\
\text { volume at } D 7(\mathrm{ml})\end{array}$ & $\begin{array}{c}\text { Plating efficiency } \\
\text { at D45 (\%) }\end{array}$ \\
\hline $\begin{array}{l}0.2 \\
0.4 \\
0.6 \\
0.8 \\
1.0\end{array}$ & $\begin{array}{l}0.79 \pm 0.21 \\
0.96 \pm 0.17 \\
0.87 \pm 0.05 \\
0.73 \pm 0.12 \\
0.50 \pm 0.02\end{array}$ & $\begin{array}{l}0.75 \\
1.00 \\
1.25 \\
1.50\end{array}$ & $\begin{array}{l}1.42 \pm 0.07 \\
1.60 \pm 0.21 \\
1.32 \pm 0.15 \\
1.25 \pm 0.07\end{array}$ \\
\hline
\end{tabular}


der a long photoperiod. Nevertheless, it was shown that a short photoperiod $(8 \mathrm{~h})$ was beneficial to obtain consistently high yields of viable protoplasts, for example in the case of Solanum $\mathrm{sp}$ or Lycopersicum esculentum (Tan et al, 1987), but no observations and comments were expressed on the effects of the light received on protoplast division. In our case, a short photoperiod gave bad results for protoplast division. The effect of the photoperiod on protoplast isolation has not been studied as we did not seem to encounter any major problems in obtaining a great number of protoplasts ( $10.10^{6}$ protoplasts/g FW) when using the Caylase enzymes, our main aim being the division of the protoplasts and their regeneration into plants.

The intensity of light received by the donor plants was also important for the plating efficiency and it varied with the nature of the light source and the species. However, in many cases the nature of the source light was not specified and our results cannot be compared with those already published. Eriksson (1977) reported that a low light intensity $\left(0.5-1 \mathrm{~W} / \mathrm{m}^{2}\right)$ is recommended, but some species, such as the potato (Bokelmann and Roest, 1983) required high intensity; it seemed that Magdeburg chicory gave similar results and that the donor plants needed a power light of $15 \mathrm{~W} / \mathrm{m}^{2}$.

These results were obtained with "Deluxe Cool White" fluorescent lamps but the use of "Gro-lux" type did not allow cellular divisions to be observed. It would be interesting to analyse in more detail the influence exerted by the nature of emitted radiations on protoplast culture, the yield of microcalli and the photosynthetic activity. On the other hand, the observed inhibitory action of "Gro-lux" fluorescent lamps may be influenced by the composition of culture medium.

The age of the plants was often studied; namely for protoplast isolation. The use of in vitro grown plants allows the physiological stage of donor plants to be standardized and we have shown that the youngest plantlets gave the best results for cellular division and bud induction.

Protoplast regeneration was studied in various Witloof chicory cultivars and we observed many differences between them. In Magdeburg chicory protoplasts, sucrose at higher rates gave better results than with concentrations used in Witloof chicory (Wali Alami-Fathi, 1987) in which $2.5 \mathrm{~g} / \mathrm{l}$ was the best concentration to obtain higher division yields. However, with another cultivar of Witloof chicory, Crepy et al (1982) used $20 \mathrm{~g} / \mathrm{l}$ sucrose. This reaction of protoplasts to carbohy- drates can be related to previous results which show the important part played by carbohydrates in the morphogenesis phenomena regulation (Sene et al, 1983; Backoula et al, 1985; Vasseur et al, 1987; Guedira et al, 1990), and also to the diversity of growth of the protoplasts according to the cultivars or the species they have been prepared from. Differences were also observed with growth substances and more particularly auxin. Magdeburg chicory required lower concentrations of auxinic substances contrary to that of Witloof chicory. Nevertheless, as in Witloof chicory, (Crepy et al, 1982), an early transfer to a low auxin medium, before the second week of culture, was essential for the development of microcalli.

Crepy et al (1982) observed the complexity of nitrogen alimentation of isolated cells and protoplasts of Cichorium species and observed that nitrogen source was a condition for plating efficiency and cell colony survival. They used glutamine as the sole nitrogen source and showed that in the MS medium, the toxicity of $\mathrm{NH}_{4} \mathrm{NO}_{3}$ was due to nitrate. In Magdeburg chicory protoplasts we observed that the association of the nitrates with glutamine was better than only glutamine as a sole nitrogen source. In Lycopersicum sp (Niedz et al, 1985) glutamine was also used in addition to $\mathrm{KNO}_{3}$. Protoplasts of dihaploid Solanum tuberosum $\mathrm{L}$ (Devries and Bokelmann, 1986) and wild pear protoplasts (Ochatt and Caso, 1986) were cultured in MS medium where the nitrogen source $\mathrm{NH}_{4} \mathrm{NO}_{3}$ was replaced by casein hydrolysate. Biester-Miel et al (1985) showed that glutamine had the same effect as casein hydrolysate. Thus it can be said that if the nitrogen source is an important factor, the needs will be different according to the plants concerned.

\section{ACKNOWLEDGMENTS}

Thanks are gratefully extended to the Etablissements Florimond-Desprez and to the Association Fondation de la Chicorée de France who supported this research.

\section{REFERENCES}

Backoula E, Lefebvre R, Vasseur J (1985) Modalités d'action du glucose sur le bourgeonnement de petits explantats racinaires de Cichorium intybus $\mathrm{L}$ cultivés in vitro. CR Acad Sci Paris 301, 639-642

Biester-Miel F, Guignard JL, Bury M, Agier C (1985) Glutamine as an active component of casein hydro- 
lysate: its balancing effect on plant cells cultured in phosphatus deficient medium. Plant Cell Rep 4, 161-163

Bokelmann GS, Roest S (1983) Plant regeneration from protoplasts of potato (Solanum tuberosum cV Bintje). Z Pflanzenphysiol 109, 259-265

Crepy L, Chupeau MC, Chupeau Y (1982) The isolation and culture of leaf protoplasts of Cichorium intybus and their regeneration into plants. $Z$ Pflanzenphysiol 107, 123-131

Devries SE, Bokelmann GS (1986) Regeneration of callus and plants from cell suspension protoplasts of dihaploid potato (Solanum tuberosum L). J Plant Physiol 122, 119-203

Dubois J, Wali-Alami F, Vasseur J (1990) Préparation, purification et culture de protoplastes foliaires de Chicorée Witloof. Bull Soc Bot Nord Fr 43, 7-16

Eriksson T (1977) Technical advances in protoplast isolation and cultivation. In: Plant Tissue Culture and its Biotechnological Application. Proc 1st Intl, Congr Medicinal Plant Research Univ Munich, Springer Verlag, Berlin, 313-333

Glimelius K (1984) High growth rate and regeneration capacity of hypocotyl protoplasts in some Brassicaceae. Physiol Plant 61, 38-44

Guedira M, Dubois T, Dubois J, Vasseur J (1990) Influence du saccharose sur le rendement, la morphologie et le développement des embryons somatiques chez Cichorium. CR Acad Sci Paris 310, 453-459

Heller R (1953) Recherches sur la nutrition minérale des tissus végétaux cultivés in vitro. Ann Sci Nat Bot Biol Veg 14, 1-223

Ludwig SR, Somers DA, Petersen WL, Pohlman RF, Zarowitz MA, Gengenbach BG, Messing J (1985) High frequency callus formation from maize protoplasts. Theor App/ Genet 71, 344-350

Morel E, Wetmore RH (1951) Fern callus tissue culture. $A m J$ Bot 38, 141-143

Murashige T, Skoog F (1962) A revised medium for rapid growth and bioassays with tobacco tissue cultures. Physiol Plant 15, 473-497

Niedz RP, Rutter SM, Handley LW, Sink KC (1985) Plant regeneration from leaf protoplasts of six tomato cultivars. Plant Sci 39, 199-204
Ochatt SJ, Caso OH (1986) Shoot regeneration from leaf mesophyll protoplasts of wild pear (Pyrus communis L var Pyraster). J Plant Physiol 122, 243-249

Saksi N, Dubois J, Millecamps JL, Vasseur J (1986) Régénération des plantes de chicorée Witloof $\mathrm{cV}$ Zoom à partir de protoplastes : influence de la nutrition glucidique et azotée. CR Acad Sci Paris 302, 165-170

Sene A, Vasseur J, Lefebvre R (1983) Sur l'aptitude de petits explantats racinaires de Cichorium intybus $L$ (var Witloof) à produire des racines adventives en culture in vitro. CR Acad Sci 297, 81-86

Shillito RD, Paszowski J, Potrykus I (1983) Agarose plating and a bead type culture technique enable and stimulate development of protoplast-derived colonies in a number of plant species. Plant Cell Rep 2, 244-247

Shneyour Y, Zelcer A, Izhar S, Beckman JS (1984) A simple feeder-layer technique for the plating of plant cells and protoplasts at low density. Plant Sci Lett 33, 293-302

Szabados L, Roca WM (1986) Regeneration of isolated mesophyll and cell suspension protoplasts to plants in Stylosanthes quianensis. A tropical forage legume. Plant Cell Rep 3, 174-177

Tan MLMC, Riet Veld EM, Van Marrewijk GAM, Kool AJ (1987) Regeneration of leaf mesophyll protoplasts of tomato cultivars ( $L$ esculentum): factors important for efficient protoplast culture and plant regeneration. Plant Cell Rep 6, 172-175

Tremblay FM, Power JB, Lalonde M (1985) Callus regeneration from Alnus incana protoplasts isolated from cell suspensions. Plant Sci 41, 211-216

Vasseur J, Lefebvre R, Backoula E (1987) Evolution des glucides intratissulaires au cours de la néoformation des bourgeons par des explantats racinaires de Cichorium intybus cultivés in vitro. Physiol Plant 69, 597-601

Von Arnold S, Eriksson T (1976) Factors influencing the growth and division of pea mesophyll protoplasts. Physiol Plant 36, 193-196

Wali Alami-Fathi FZ (1987) Préparation et culture de protoplastes de Cichorium intybus $\mathrm{L}$ var Witloof: Amélioration des rendements. Thèse de Doc $3^{\circ} \mathrm{cy}-$ cle Lille 